\title{
A SKETCH OF NORTH SYRIAN ECONOMIC RELATIONS IN THE MIDDLE BRONZE AGE*
}

\author{
BY \\ JACK M. SASSON \\ (The University of North Carolina)
}

Northern Syria of the Middle Bronze Age, as known chiefly from the archives of Mari and Alalah VII, slowly graduated from moments of relative chaos ( $c a .2100-1850$ ) to an age of political stability (ca. I850-1625). Under the able leadership of the Yamhadian dynasty, a feudal system of relationship created one entity out of the whole region. ${ }^{1}$ ) The evidence at our disposal allows us even to imagine a political and economic Pax Yambadiana which, beginning before the fall of Mari, lasted until the rise of the Hittite State and the attacks of Hattusilis I (ca. 1625).

*) The word 'sketch' in the title is chosen for reasons of necessity. Except for brief illuminations from the 'Cappadocian' texts and those from Egypt, heavy reliance had to be placed on the Mari and Alalah VII documents, and then only when they show evidence of foreign interconnection. The archaeology of Middle Bronze (IIa) Syria, in which the Mari age unfolds, has not been very helpful, simply because not enough North Syrian sites of that age have been excavated. The reports from the 'Amuq region (phase L), 'Aț̌anah (levels XVI-VIII), testify to a widespread use of a painted ware rounded of form, narrow necked, buff, with simple geometric designs (cross-hatching in triangles) within bands (cf. Iraq, Is (1953), 57-65; Cbronologies in Old World Archaeology, p. 172). The material from Ugarit of that age being yet mostly unpublished, one looks forward to the reports of excavation at Tilmen-Hüyük, which is probably the site of ancient Ibla (for now, see Orientalia 33 (1964) 503-507; $A J A$ 68 (1964), 155-56; 70 (1966), 147). There, some ten kilometers southeast of Zinçirli, level IIIa-c seems to correspond to Mari of the YahdunLim dynasty. The chronology adopted is that employed in the second edition of the Cambridge Ancient History. This study benefitted from the comments of Professors Michael C. Astour and William W. Hallo. Professor Harry A. Hoffner, Jr., has also been most helpful.

I) For the political history of Northern Syria during the Middle Bronze Age, see Horst Klengel, Geschichte Syriens im 2. Jabrtausend v.u.z., $I$ (= Deutsche Akademie der Wissenschaften zu Berlin: Institut für Orientforschung. No. 40), I965, chap. 4, 7, 8, 14-16; J. R. Kupper, "Northern Mesopotamia and Syria," $C A H^{2}$, II: I (1963), with an excellent bibliography. In order not to elongate this study, a number of secondary materials cited there will not be repeated. 
In general, it was also an era in which West Semitic families successfully dominated the Fertile Crescent from Sat-el-'Arab to the valley of the Nile. In the East, the dynasty of Hammurapi was to remain secure as ruler of Sumer and Akkad; its pre-eminence shattered only by Muršilis' raid upon the capital, Babylon (ca. 1595). To the West, the Hyksos began to infiltrate Palestine and Egypt, achieving complete control over the Eastern Delta by 1720.1 ) As they peaceably brought into Egypt the same ethnic element as was present in Northernmost Syria of the eighteenth century, ${ }^{2}$ ) new waves of Hurrians slowly entered from the east, possibly trickling even from the west, ${ }^{3}$ ) and filled the vacuum. The latter were to become revitalized when, a century later, Indo-European groups forged a strong new state, Mitanni, in North Mesopotamia east of the Euphrates.

As the peace was enforced by a strong Yamhad, North Syria traded with its neighbors, taking full advantage of its geographical situation. ${ }^{4}$ ) Flanked by the Mediterranean on the west, the Euphrates on the east, and bounded to the north by Asia Minor, to the southeast by Mesopotamia, North Syria offered its output to the other lands. In addition, it was in a position to effect the interchange of products among Crete, Egypt, Mesopotamia, and Anatolia.

To be sure, the fall of the Ur III dynasty brought about radical changes in the method and orientation of Mesopotamian trade. The

I) W. C. Hayes, "Egypt to the End of the Twentieth Dynasty, Chronology," $C A H^{2}$, I, 4, p. I 3 ff.; idem, $C A H^{2}$, II, 2, 18 ff.

2) But cf. Helck's treatment of the situation in his Beqiebungen, chap. XIII (with appropriate bibliography). He prefers to see in the early Hyksos a wave composed of Hurrian infiltrators. Säve-Söderbergh had, before the publication of Helck's work, published an article in which he challenged the then widespread assumption that the Delta was invaded by Hurrians. "The Hyksos Rule in Egypt," JEA, 37 (I95 I), pp. 53-7I, can still be considered as a good defense against Helck's arguments. Cf., further, Kupper, $C A H^{2}$, II, I, pp. 38-4I.

3) By the end of the third millennium, Anatolia had a substantial number of Hurrian settlers (Garelli, Les Assyriens en Cappadoce, I5 5 ff; H. Levy, $C A H^{2}$, I, 24, If VII-X, p. I3). Haššum and Ursum, northwest of Carchemish were ruled by Hurrians in the Age of Mari.

4) On the pitfalls of speculations concerning trade at such an early date, see Leemans' review-article of Heichelheim's An Ancient Economic History, I (Leiden, 1958), in JESHO, 6 (1961), pp. 106-I I 2. 
kings of the Neo-Sumerian empire had created a system of trading in which little role was played by a tamkärum who was unattached either to the palace or to the temple. ${ }^{1}$ ) Following the nomadic engulfment, as Falkenstein noted concerning the latter, "c'en était désormais fini du rôle qu'ils avaient joué jadis comme centre dirigeant de toute l'économie et de toute l'organisation politique."'2) A system in which a freer hand was permitted to an ambitious individual promptly emerged. Even more radical a shift in economic outlook becomes recognizable. The Mesopotamian lands transferred their mercantile horizons from the Persian Gulf areas to those west of the Euphrates, Northern Syria, and beyond. So that materials which were readily obtainable from the south and the southeast had to be sought in western markets. This shift, becoming more pronounced after the fall of Larsa, no doubt resulted directly from the atrophied state of many Sumerian cities which, in turn, was caused by the West Semitic occupation of these polities.

The rivers, especially the Euphrates, increasingly bore the burden of the trade of this new age. ${ }^{3}$ ) Boats of all sizes are mentioned very frequently in the texts, sharply contrasting the relatively rare mentions of donkey caravans. ${ }^{4}$ ) The ships docked in a quay, the karrum of Old Babylonian times, an area where goods were displayed, bought, and

I) One should note that the greatest number of Neo-Sumerian documents come from either temple or palace archives. For examples of apparently private enterprises during that time, see, Leemans, The Old Babylonian Mercbant (Leiden, 1950), pp. 45 ff.

2) A. Falkenstein, „La cité-temple sumérienne," JWH, I (1953), p. I 83 ; similar notion expressed by Gadd, $C A H^{2}$, II, s (1965), 19-20.

3) M. Birot, review-article of Leemans' Foreign Trade, JESHO, s (1962), pp. IOI-IO3.

4) Leemans, "Trade Relations of Babylonia and the Question of Relations with Egypt in the Old Babylonian Period," JESHO, 3 (1960), pp. 33-34. Though the latter was by no means negligible. In order for goods to reach inland, to the cities of Aleppo, Qatna, and Hașor, donkey caravans were employed. $A R M$ I: 66 (also I: I7) speaks of provisions, enough to last for ten days, were necessary to cross the expanse between Terqa and Qatna, Hallo, JCS, 18 (1964), 86. On the subject of both water and land travel, Salonen's Die Landfabrzeuge des Alten Mesopotamien (Helsinki, 195 I), and Die Wasserfabrzeuge in Babylonien (Helsinki, 1939) can be used with profit. On the road system of Mesopotamia and Syria in the Old Babylonian period, see Hallo, op. cit., pp. 86-88. 
sold. ${ }^{1}$ ) Often at the risk of life and $\operatorname{limb},{ }^{2}$ ) foreigners established a trading post in the kärum of a busy city..$^{3}$ ) The many foreigners, whose names were recorded in the archives of Mari, probably were hired artisans, demioergoi so to speak, but a number of them may have been traders. ${ }^{4}$ )

Since Mesopotamia was a land almost totally lacking in mineral resources, it could have prospered only when it capitalized on transit trading. In the Middle Bronze Age, and especially after the West Semitic invasions, Babylonian traders imported tin from Elam, ${ }^{5}$ ) before scattering it to the north ${ }^{6}$ ). Mari purchased large quantities from the same region. Thus, ARM VII: 233 (also IX: 288) records two Elamites, Innerri and Kayaya, who delivered some one hundred kilograms of the precious metal. From there, as the same text shows, a good portion of it was sent to Yarim-Lim of Aleppo (cf. also VII: 86; $87 ; 88 ; 233$ and 236). Similar shipments were made to Carchemish (VII: $86 ; R A, 35$ (I939), I I9), Qatna (VII: 87; 88) and Hașor (VII: 236).7) Whether direct exports were also effected to Alalah VII, or whether the latter found supplies in neighboring lands cannot, as yet, be determined..$^{8}$ )

An interesting example of royal involvement in the tin trade can be gleaned from the ill-humored letter which Išhi-Adad of Qatna sent to Išme-Dagan, then viceroy at Ekallatim. Noting that his gift of two

I) $A H w$, p. 45 Ib. But see the remark of Oppenheim: "Archaeological evidence speaks against the existence of 'market-places' within the cities of the Ancient Near East," in Trade and Market in the Early Empires (Glencoe, 1957), p. 16, Cf. the criticism of Heichelheim in JESHO, 3 (1960), p. 109

2) As was apparently more common in the Late Bronze Age, see now Sasson, $J A O S, 86$ (1966), pp. I $37^{-1} 38$..

3) A Kărum was established by Sippar merchants at Mari and at nearby Mišlan, W. F. Leemans, Foreign Trade in the Old Babylonian Period (Studia et Documenta... VI), 1960, p. 106, 16a: 5 .

4) See below.

5) Possibly from the region later known as Drangae, Strabo, 7: 145 .

6) Leemans, Foreign Trade, p. I 29.

7) See the discussion of Bottero, $A R M T$ VII, pp. 293-295 $\left(\llbracket 87, \mathrm{I}^{\circ}\right)$.

8) AT * 4I4. Later, large quantities of tin and copper were noted in one document from the fourth level, AT 399 . From the indications, Forbes concluded that a good quality bronze (8 per cent tin) was manufactured, Studies, (X (1964), p. 153. 
horses was worth 600 shekels of silver, the king of Qatna remonstrates against the dispatching of a paltry twenty mina of tin as an acknowledgment. "One cannot really say such a thing," he writes, "yet, in truth, I say it to unburden my mind ... whosoever hears of this [exchange of gifts] will not place us on the same footing. If you had not sent any tin, my heart would have never been grieved. Are you not a great king? Why have you done this? ( $A R M \mathrm{~V}: 20)$ " As the ratio of tin to silver fluctuated between 14: I ( $A R M$ VII: 233) and 10: I (VII: 88), 1) Išhi-Adad seems to have been presented with either one-fifth or oneseventh the value of his gift. ${ }^{2}$ )

As a cattle-raising, barley, date, and sesame-growing land, Mesopotamia produced a limited variety of goods to offer north Syria. ${ }^{3}$ ) On the other hand, Babylonia began to depend upon the north for an ever-increasing number of materials, especially since the trade with Dilmun, Magan, and Meluhha was sharply curtailed after the collapse of the southern cities. In the absense of those elements on which a barter economy depends, silver increasingly assumed the role of an international trading medium. ${ }^{4}$ ) Leemans observes that, especially at Larsa in the period following the one in which southern connections were severed, the flow of silver seems to move from North to South. As an example, the Sippar merchants received payments in silver for the goods that they shipped towards the upper regions. ${ }^{5}$ ) But as the

I) See Bottero, $A R M T$ VII, pp. 293-295 $\left(§ 87, \mathrm{I}^{\circ}\right)$.

2) Twenty minae of tin equalled $\mathrm{I} 200$ shekels. This amount was valued at $\mathrm{I} 20$ (at I: 10 ) or 85 (at I: 14 ) shekels of silver.

3) For a listing of its products and exports, see Leemans' Foreign Trade, pp. I I4- I I6, 1 28-1 29. An example of a product, albeit finished, shipped from south to north, see the text republished by Leemans, ibid., pp. I09-I 10, in which a Babylonian merchant records the sale of garments to Qatna.

4) Whether silver was employed as means for payment in Ur III is still not clear. Leemans finds "no evidence that imports into Ur from overseas were paid for in silver in the time of the third dynasty of Ur." (Leemans, Foreign Trade, p. I30.) In studying documents from other Ur III sites, Curtis and Hallo tentatively conclude that silver often served as money in addition to the hard-to-perish commodities more commonly employed in barter. Furthermore, they suggest "that silver as money was primarily used by the merchants in the neo-Sumerian period." ("Money and Merchants in Ur III," HUCA, 30 (1959), pp. 108, I1 2.)

s) Leemans, ibid., p. I31, n. I. 
number of objects imported into Mesopotamia was much greater than that exported to Syria, this inflow of silver from North to South is certainly paradoxical. It becomes even more problematic when it is remembered that the source of silver during that era appears to have been centered in Anatolia and North Syria. ${ }^{1}$ ) A solution to this difficulty is suggested by the number of texts found at Mari which preserve the rate of transit-duty, miksum, imposed on boats delivering material from the north to the south. Evidently, fluvial transport had been extensive enough during the Old Babylonian period to balance any trade deficit which might have originated from the unfavorable flux of goods. ${ }^{2}$ ) Another form of income which permitted Babylonia to attract the silver from Northern Syria was undoubtedly created in urban centers. There, native materials and perhaps also raw materials imported from Syria were employed in the manufacture of finished products destined for northern markets. ${ }^{3}$ )

In some cases, gold is known to have been used as a medium of payment during the Age of Mari (V: 72: $23 \mathrm{ff}$.; VII: 217; VIII: 86), but the evidence is more positive in favor of the metal's employment for decorative purposes. ${ }^{4}$ ) Comparisons with Late Bronze Age Syria, Palestine, and Mesopotamia when gold had become the standard in trade, ${ }^{5}$ ) suggest that the metal's relative scarcity during the Middle Bronze period was a direct consequence of the limited connection between Western Asia and Egypt, the chief supplier of gold. ${ }^{6}$ ) Except

I) Forbes, "Lead and Silver in Antiquity," JEOL, 7 (1940), 492-93; Studies in Ancient Tecbnology, VII (1964), map, p. 193. Silver was mined in Anatolia (cf. URU $K u$-uq-za in KUB II: 2 obv i. 44, KBo IV I obv. i 36 ). There is also the possibility of some deposits to have existed in Jebel Akra, a few kilometers west of Alalah. The KUR.KUR.KUG ( $P B S$, I 5 (1926), No. 4I) of Sargon of Agade may be associated with this region rather than with the Anatolian Bulgar ma'den.

2) Burke, Syria, 41 (1964), pp. 102-103; $A H w$, p. 652, sub. miksu(m).

3) A list of close to a thousand persons that were employed in the manufacturing of cloth is published in $A R M T$ XIII: 1 .

4) Bottero, $A R M T$ VII, p. $297\left(\$ 87,6^{\circ}\right)$.

5) Edzard, JESHO, 3 (1960), pp. 38-55: $C A D, \mathrm{H}: 246 \mathrm{~b}$. Cf. the forthcoming article "Gold" in RLA.

6) There seems to have existed a deposit of gold in the region of Hahhum, located by Goetze (Kleinasien ${ }^{2}$, p. 74, n. 2) between the Halys and the Euphrates. Gudea 
at Byblos, where politics definitely favored the Two-Lands, and at Ugarit, where an Egyptian contingent of merchants was probably settled, ${ }^{1}$ ) Nilotic relations with North Syria seem to have been severely curtailed. ${ }^{2}$ )

Limited as these relations appear to have been, Egypt of the Twelfth and Thirteenth Dynasty did not exist in a vacuum. A number of objects, which could have been gathered only through trade with the east, found their way into Egyptian tombs. One such materials was lapis-lazuli, a stone whose import from Tfrr in Afghanistan undoubtedly passed through Mesopotamian and Syrian hands. ${ }^{3}$ ) The Tōd treasure, apparently a gift from a Levantine principality to Amenemphet II, contained a number of lapis-lazuli articles. ${ }^{4}$ ) This rich find, by itself, constitutes an important, albeit enigmatic, testimony to the rapport between the two continents. ${ }^{5}$ ) Another indirect indication of Egyptian dependence on Asia, is the sporadic attestation, during the Middle Kingdom, of Syrian timber. Such evidence occurs both in texts, ${ }^{6}$ ) and in actual find cedar, cypress, and yew employed mostly in the manufacture of coffins. ${ }^{7}$ ) Pottery, distinct in its Asiatic character-

brought gold from there and from the mountainsof Barsip . (Statue B $1.33 .59=$ SAKI, p. 70-7I.) For further remarks on silver and gold, especially in the late third millennium, see H. Limet, Le travail du métal au pays de Sumer (BFPL, Université de Liège, No. I55). The Hittite source for gold was URU Perundummeya (KBo IV I obv. i 35 ; KUB II: 2 ob. i 45), to be located, possibly, in Anatolia itself.

I) Helck, Beqiebungen, pp. $64-65,69$.

2) Qatna has produced a sphinx dating to the time of Amenemhet II, and Neyrab one belonging to that of Amenemhet III, ibid., p. 69 .

3) According to Hittite sources, KBo IV I obv. i 36 ; KUB II: 2 obv. i. 45 , a source of lapis-lazuli, was to be found in Mount Takneyara. To judge from the -ara ending, common in Anatolian toponymes, this site is to be located in Asia Minor.

4) Lucas, Materials 4 , p. 309.

5) J. Vandier, „A propos d'un dépot de provenance asiatique trouvé à Tôd," Syria, 18 (1937); Kantor in Cbronologies in Old World Archaeology, 19-22. Cf. W. F. Leemans. JESHO III (1960), p. 22.

6) Helck, Beziebungen, p. 72 .

7) Lucas, Material ${ }^{4}$, pp. 429-439. Although there is no direct evidence at our disposal, one can still surmise a lively trade with north Syria to have been maintained by the Egyptian City of the Dead. Throughout the history of the Ancient Near East, this trade was to remain of prime importance as raison-d'être for Syro-Egyptian 
istics, forms yet a third affirmation for Egypto-Semitic relations. ${ }^{1}$ ) Among the most significant import into Mari and the rest of Mesopotamia in the Middle Bronze Age was copper. One source of the metal, essential for the production of bronze, may have existed in the mountainous area near the Upper Euphrates. ${ }^{2}$ ) The Mari archives contain a letter from Aplahanda of Carchemish addressed to YasmahAdad ( $A R M \mathrm{~V}: 6: 4-9)$ : "Now, there is copper ore at Zirānum [doubtlessly near Carchemish]. It is abundant. Place your servants as guards to watch it for you." From an earlier time, Old Assyrian tablets indicate the presence of copper in the same range. CCT 42a:21-23 reads: "Io manā' é eri'am ba-sú-a-am ištu alim ${ }^{K I}$ uśakšidam," 'ten minas of

relations. For the purpose of mummification a number of derivatives, which were obtainable then only from Syrian timber, were required. It is possible that such were manufactured by the Egyptians after importation of the appropriate logs. It is more likely, in view of the number of Syrian unguent jars discovered in the TwoLands as early as the predynastic era, that they were exported as end products by north Syrian tradesmen. Among other materiels, the embalmer requested cedar oil, really an extract of the juniper-tree, with which he anointed the corpse. Juniper berries and beads of resin have been found in graves of the third Dynasty onward. They were deposited upon the mummy, serving either a ritual function or a fancied preservative purpose. Aromatic sawdust, a product of the juniper, was used in stuffing body cavities. Wood pitch and wood tar, again probably derived from the juniper, were also needed for the process. Chia of turpentine, which was extracted from a north Syrian shrub, is known mainly from later periods of Egyptian history; its employment seems to have had religious significance. These north Syrian tradeitems do not complete the list of objects sought by the Egyptian mortician. For a fuller listing, see A. Lucas and J. R. Harris, Ancient Egyptian Materials and Industries', 1962, chapt. I 2, especially pp. 309-326. For a survey of Syrian and Lebanese extensive wooded areas during the second millennium B.C., see M. B. Rowton, "The Topological Factor in the Hapiru Problem," Landsberger Festscbrift (1965) (= Assyr. Stud. \#16), 376-82.

I) Helck, Beriebungen, pp. 73-75.

2) Ch. Virolleaud, „La montagne du Nord,” Babyloniaca, 17 (1937), 145-I55; Reallexicon der Assyriologie, I 395 A. Schaeffer argues for the presence, in the Kesruwan district, some six kilometers from Byblos, of copper, Ugaritica II, p. $67 . \mathrm{He}$ and Wainwright [the latter quoting Strabo (III: 2, 9), Pliny (XXXIV: 47), and Diodorus (v: 2I)] believe in the existence of naturally-alloyed bronze in the same area. See further, Antiquity, 17 (1943), 96-98; 18 (1944), 57-64; $J E A, 3$ I (1945), 32-5. Cf. H. Limet, Le Travail du metal au pays de Sumer (= BFPL Université de Liège, I55), pp. 64, 97. For other North Syrian deposits of copper see the remarks of J. Lewy, "Studies in the Historic Geography of the Ancient Near East," Orientalia, 2 I (1952), $417 \mathrm{ff}$. 
Haššum copper was brought from the city (Assur).' ${ }^{1}$ ) A town in North Syria was called Sipri (modern Sfire, some $12 \mathrm{~km}$. southeast of Aleppo). As Dossin suggested, the name may have been derived from Akkadian siparru, 'bronze,' indicating perhaps that copper and bronze were mined and worked there. ${ }^{2}$ ) When ARM VII: 135:7 records the purchase of seven talents of 'mountain copper $(7 \mathrm{GU}$.URUDU.KUR-i),' it is conceivable to fix Northern Syria as the point of its origin. ${ }^{3}$ )

Also exploited in the Mari era were the copper mines of Mount Taggata in Alašia, Cyprus. Dossin cites three instances in which alašia copper was brought to Mari. ${ }^{4}$ ) That the ore was exported to this city through the intermediary of Syrian tradesmen, it is logically plausible. The archaeological evidence which testifies to the relations between Syria and Cyprus is abundant. In his study, The Middle Cypriot Bronze Age, Paul Åström proposes to lower the chronology of that Island's Middle Bronze period, precisely by considering the great variety of wares exchanged between the mainland and Cyprus.5) Early in this era, one which was somewhat equivalent in age to the settlement of the West Semites in Northernmost Syria and Mesopotamia, the island was torn between two sets of cultures. One, based on the northern coast, preserved and continued the traditions of the Early Bronze Age, deriving its civilization from the Aegean and from the Anatolian Peninsula. The second, gradually gaining in predominance, looked to the newly created states of Syria and Palestine for trade and cultural inspiration. Lapithos, a few kilometers west of Kyrenia in the north, had been the main center of M.C.I. But it was soon to be(supplanted

I) Lewy, Orientalia, 2 I (1952), pp. 420-423, 420, n. 2.

2) Dossin, $R A, 42$ (1948), p. 30; Lewy, Orientalia, 2 I (1952), p. 42 I. Note also that Gebel-al-Arba'in, southwest of Alalah, was a place where copper was anciently melted, (ibid., p. 4I7).

3) On the other regions whose copper mines supplied Mesopotamia, see Leemans, Foreign Trade, pp. I 21-23. But note also Birot's important remarks on the same subject in his review of Foreign Trade, JESHO, s (1962), pp. 98-99.

4) Dossin, Syria, 20 (1939), p. I I I.

5) Published in Lund, 1957. See his chapters on 'Foreign Relations' and 'Absolute Chronology.' 
in M.C. II-slightly before Hammurapi-by Kalopsidha on the southern coast, some sixteen kilometers from today's Famagusta.1) The reason for Lapithos' attrition may, perhaps, be connected with the IndoEuropean invasions of Anatolia, late in the third millennium, which resulted in altering the pattern of foreign trade and consequently, of urban settlement. ${ }^{2}$ )

In Middle Cypriot III, corresponding to the last moments of the Mari period, the contacts between Cyprus and North Syria were so frequent that, as Aström declares, he "is tempted to assume Cypriot trading factories at sites such as Ras-Shamra. ${ }^{3}$ ) On the other hand, West Semitic culture invaded the island; shortly it was to emerge triumphant.. ${ }^{4}$ ) Toggle-pins and shaft-hole axes, objects made of copper which was native to Cyprus, were inspired by Near-Eastern models. It is perhaps not by accident that Kinyras, a Cypriot with a typically West Semitic name, ${ }^{5}$ ) became fabled as the discoverer of copper metallurgy and as the inventor of bronze instrurnents (Pliny, VII: 195; Iliad, XL: 20).

I) Schaeffer calls Kalopsidha „une colonie syrienne dans la région côtière orientale en Chypre," Mission en Chypre (1932-1935), p. 69. Flowever, this is probably an exaggeration.

2) Mellaart, $C A H^{2}$, I, 24, VI. Cf., also, H. W. Catling, "Cyprus," $C A H^{2}$, II, 42 (1966), p. 45. One problem, however, remains, and that is the identification of Alašia with a point in Cyprus. Åström remarks: "Mr. [James] Stewart, who is not convinced that Alašia was part of Cyprus, nevertheless suggests the possibility that if Alašia was Enkomi during the Late Bronze Age, it may have been Kalopsida during the entire second millennium." Middle Cypriot, p. 277, n. I. Alašia, it is better to state, was probably the name given to be the whole island. As was commonplace in the ancient Near East, the city which was most prominent at a certain time bore the name of the whole region. But cf. Catling's remarks in $C A H^{2}$, II, 22 (b), 58-62.

3) Åström, ibid., p. 278. Among the Cypriot pots favored in Western Asia and Egypt were the Composite-Ware bowl, known best from Kalopsidha, and a WhitePainted III-IV pendant sylte jug, exported in some quantities in Ras-Shamra. p. $212 \mathrm{ff}$.

4) The Habur ware of Syria became popular in Cyprus around 1800 , ibid.

5) In a list concerned with divinities found at Ugarit, DINGIR. GIŠ-ki-na-rum is paralleled by Alphabetic knr (Nougayrol, $C R A I$, 1957. 82). As suggested by Jirku in his „Der Kyprische Heros Kinyras und der Syrische Gott [il is] Kinäru(m)," Forscbungen und Fortscbritte, 37 (1963), p. 211 , Kinyras derives from the name of that deity. The last, it might be added, depends upon the West Semitic term for the lyre. On Kinyras, see further, Dussaud, Syria, 27 (1950), pp. 57-81 ; J. P. Brown, JSS, IO (1965), 197-219. 
To complete the study of Middle Bronze Syria's trade in metals, it will be well to mention the traffic in iron. Earliest finds of this metal in the coastal region come from Byblos, dating to the mid-nineteenth century. To be sure, archaeological evidence for its presence in Egypt and Mesopotamia have been uncovered from appreciably earlier periods.1) But attestation of iron in epigraphical documents from Cappadocia, Mari, Alalah, and Boghaz-Köy (KBo IV: I, events attributed to the era of Anitaš of Kuššar), have led Bottero"... [à] se demander si le fer n'était pas moins rare à l'ouest qu'en Mésopotamie proprement dite."') Although there is no doubt that terrestrial iron was in use at this time, the metal was rare enough to permit the fabrication of only the smallest objects. Thus it was with pride that Aplahanda of Carchemish sent to Yasmah-Adad a bracelet of iron (written BAR.AN; ARM V: (:9). ${ }^{3}$ ) Later, Alalah of the seventh level yielded a text (AT*410:13) in which 400 arrow-heads of iron were recorded. $\left.{ }^{4}\right)$

An acquaintance with Yasmah-Adad's personal conduct and habits permits one to suppose a healthy eagerness with which he welcomed Aplahanda's other presents. "With this messenger," wrote the king of Carchemish, "I am dispatching to you excellent wine; drink! At the same time I am sending victuals; eat!" Again, he once solicitously asked: "If with you there should not be good wine which you could drink, write to me and I will send excellent wine for you to drink." '5) Yasmah-Adad was not the only Mesopotamian to have been blessed with a sweet palate for, as Old Babylonian documents demonstrate, wine was shipped in very large quantities downstream from Northern Syria. Under Yarim-Lim and Hammurapi, Halab sent Mari roo and s karpätu, 'jars,' respectively ( $A R M$ VII: 238: 17; IX: 33: 1). To be regarded as commercial ventures rather than outward gifts are the two,

I) Forbes, Studies $I X$, pp. 232, 224, 247. See his chapter III, $7^{\circ}$ (pp. 220-27I), for a full discussion of the early history of iron.

2) Bottero, $A R M T$ VII, p. 301 ( $\left(\$ 87, \mathrm{I}^{\circ}\right)^{\circ}$.

3) Compare the spelling BAR.GAL for iron (CT XVII: 29: 5 ra); Deimel $\breve{S L}$ III, p. I4b.

4) But see the sobering remarks of Bottero, ibid.

5) $A R M$ V:5:4-8; 6: 13-17. See also V: 13:6, $R A, 35$ (1938), pp. I17-119. 
consigments of 100 and so jars (VII: 257: I; V: 9: 5) attributed to Aplahanda. His son Yatar-Ami was responsible for sending nearly 300 (IX: 17: I-3). One juridical document, $A R M$ VIII: 80 , speaks of 500 measures of wine sold together with their empty jars. As two of the witnesses, Ilulla and Dariya, are known to have been citizens of Carchemish, ${ }^{1}$ ) the beverage involved in this transaction can be considered as purchased from Northernmost Syria. ${ }^{2}$ ) Birot tentatively estimates the capacity of a karpätum, 'a jar,' to have been Io qa. ${ }^{3}$ ) If Bottero's suggestion that a qa roughtly equalled one liter is correct, ${ }^{4}$ ) then a single shipment of Carchemishian wine reached the proportion of I roo gallons. A little more than half a century later, Alalah VII will show interest in viticulture ( $A T$, p. 16r).

Another liquid, the exportation of which from Northern Syria is indicated in the Mari archives, was derived from the boiling of sesame and the pressing of the olive..$^{5}$ ) Olive oil, known as İ.GIŚ$Z I-I R-D U$ (Boghaz Köy ZE-ER-TA/TUM) was shipped to Mari from Yamhad ( $A R M$ VII: 238: I6) and perhaps from Carchemish (VII: $257: 3$ ). As consignment of this type of oil rarely exceeded modest proportions, usually less than ten karpätu, it is possible that its employment was reserved for cosmetic and medicinal purposes. When $A R M$ IX: 6 speaks of one ugar, roughly equivalent to 264 gallons, of olive oil, it may, however, imply that the liquid was, in this case, destined for kitchen duty. It is important to note that this large shipment was brought to Mari by Kutkutum, a West Semite who, apparently, came from Northern Syria. ${ }^{6}$ )

1) Ilulla: ARM VII: I 59: I6. Dareya: ARM VII: 86:[18]; IX : 17:4;Arch. Orient. 17 (1949), 329; B: 30. See further Sasson $R H A 79$ (1966), forthcoming.

2) From the time of Ammișaduqa, (ca. 1646-1626), a text mentions Carchemishian wine at Sippar, Leemans, Foreign Trade, p. 103. On wine and its production in the Ancient World, see Forbes, Studies, III (1955), pp. 70-78.

3) Birot, $A R M T$ IX, p. 50 (9).

4) Bottero, $A R M T$ VII, pp. 350-35 I (1 30).

5) Often, it is not possible to determine its exact derivation. On the problem, see Bottero, $A R M T$ VII, p. $266\left(\$ 71,15^{\circ}\right)$.

6) Birot, $A R M T$ IX, p. 268 (\$34), regards the latter as a merchant from North Syria, a citizen of either Halab or Carchemish. There is little doubt that North 
Other imports of larger quantities undoubtedly consisted of sesame oil. ${ }^{1}$ ) It is well to remember in this connection Herodotus' statement on the mores of Babylonia: "The only oil these people use is made of sesame (I: I94)." One tablet (IX:9) mentions the conversion of 610 gallons of unspecified type of oil, but probably sesame oil, into 450 gallons of a purer quality. Here it is detailed that Alahtum, a Yambradian city, was the place of export. In addition to Yamhad and Carchemish, other North Syrian localities produced highly reputed extracts. Cappadocian texts single out the oil product of Hahhum. ${ }^{2}$ ) ARM V: 63, a letter from a Mari functionary to his lord, YasmahAdad, contains the following: "As to the oil of Tunip [in the Orontes Valley] concerning which my lord has written, there is no Tunipian oil in my possession. Thus I could not send any. But as soon as I heard, I wrote immediately to Aleppo. If they should ship (some) to me, I will dispatch (it) to my lord."

While figs, dates, and musts were employed as sweetening devices in the Middle Bronze Age, honey was by far the most widely used sugar substitute. As such it was even used to flavor beer and wine. In addition, its employment in temple ritual became prevalent, perhaps during the same era, in Mesopotamia, Canaan, and Egypt. ${ }^{3}$ ) No less important was its effectiveness in curing all sorts of diseases. ${ }^{4}$ ) As apiculture seems not to have existed in Mesopotamia until Neo-Assyrian times, ${ }^{5}$ )

Syria was and had been the main supplier of olive oil. Vast oil-producing installations were uncovered at Ugarit of the Early Bronze Age, Ugaritica IV, 420-433.

I) For the possible price of oil in the era of Mari, see Burke, Syria 41 (1964), p. 79.

2) Lewy, Orientalia, 2 I (1952), p. 273, n. 3.

3) The oldest Akkadian texts mentioning honey in ritual contexts come from the Old Babylonian period, CAD, D: I62. Egypt employed large quantities in the temple of Min, Montet, „Études sur quelques prêtres et fonctionnaires du dieu Min," $J N E S, 9$ (1950), p. $18 \mathrm{ff}$. For Canaanite usage, which probably resulted in a direct divine injunction against the employment of honey in the ritual of Israel, see the references in UT: 19: 1602 .

4) For Babylonia, consult CAD, $D$, pp. $16 \mathrm{r}-162$, s.v. dispu. For Hatti, e.g., KUB 4: 49: ii 2. For Egypt, Lucas, Materials ${ }^{4}$, pp. 25-26.

5) Forbes, Studies, V (1957), p. 86. See further his article, in that volume, 'Sugar and Its Substitutes in Antiquity,' pp. 78-109. The first attempt at introducing beecultures in Mesopotamia did not take place until well into the first millennium B.C., 
Mari imported the product from various areas in North Syria. $\left.{ }^{1}\right)$ An Old Assyrian text from Kültepe (BIN IV: 219) informs that Uršu was a particularly productive region. But the quantities imported into Mari were generally minimal.2) Yarim-Lim dispatched no more than Io jars (VII: 238: 17). Aplahanda, while sending only 1o jars to ZimriLim (VII: 257:2), once proffered fifty so Yasmah-Adad, a man who, no doubt, appreciated it more $\left(V: 1_{3}: 7\right)$.

Later, Palestine and Canaan, famed as lands of 'milk and honey', were to supply the victorious pharaohs of the eighteenth dynasty with great amounts of the product. ${ }^{3}$ )

Although a large variety of natural products were exported from Northern Syria to the sadly lacking regions of Mesopotamia and Egypt, actual epigraphic evidence rarely specify the point of origin of many of them. But there is little doubt that the timber, resin, and ivory mentioned in the economic documents were directly imported from the Amanus region. ${ }^{4}$ ) As yet, we read only of Carchemish exporting five talents of pasallu, possibly a stone of semi-precious quality $\left(A R M \mathrm{~V}:\right.$ 13:9-10). $\left.{ }^{5}\right)$ On another occasion, we read that, despite its

under the auspices of Samaš-reš-ușur, governor of Suhi-province, ibid., pp. 86-87; $C A D, D: 16_{3}$ e. One cannot rule out the possibility that dispu/LAL was manufactured from dates and grapes. Such a confection, however, was usually indicated in the writing of the term, e.g., $C A D: D:$ p. $16_{3}$ f: $4-5$.

I) The Syro-Lebanese region had, in the second millennium B.C., large stretches of maqui whose shrub was abundant with the flowers necessary for the production of honey. Rowton, Landsberger Festscbrift, p. $37^{8}$.

2) Bottero, $A R M T$ VII, pp. 26 I-262 $\left(\$ 70,7^{\circ}\right)$; Birot, $A R M T$ IX, pp. $270-271$ (39). Two unpublished OB texts cited by Rowton, Landsberger Festscbrift, p. 387 , n. I6, make it evident that honey was an expensive commodity.

3) $B A R$ II, 462, 518.

4) See above; Bottero, ARMT VII, pp. 336-337 (I I s); Leemans, Foreign Trade, pp. 1 24-1 26. Great inland supplies of salt existed near Aleppo. It was widely used as a meat and fish preservative, food seasoner, and sacrifice purifier. Salt was even employed to spread a crust of infertility over the soil of conquered fields and cities. Although it must have been shipped to Egypt and Mesopotamia during the Mari period, we possess evidence of its trade only from Ugaritic documents. UT 2096-7 speak of an order of 1800 jars, evidently readied for export. As the name implies, a red colored salt, the teabat amäni, was imported to Mesopotamia from the mountains of Upper Syria. It seems to have been compounded in medical prescriptions. ( $A H_{w}$ p. $4^{\circ}$ ).

5) Burke, Syria, 4I (1964), pp. 75-76, speculates that the millstones (NA4.HAR) 
abundance in Mesopotamia, grain was sought from Northernmost Syria. Thus, when faced with famine, Zimri-Lim begged his father-inlaw in Yamhad to ship to him a large quantity.1) $A R M$ XI: 14 discloses the exportation of a modest amount, no more than I 80 qa, of $\operatorname{sam}(m) i d a-$ tum, 'semolina,' from Emār, a Yamhadian city with outlet on the Euphrates. $\left.{ }^{2}\right)$

The raising of livestock was essential to the economy of ancient man, whether in Mesopotamia, Canaan, or Mesopotamia. The Mari Archives often speak of large herds of cattle, large and small, and and beasts of burden. ${ }^{3}$ ) As indicated by those same texts, Northernmost Syria, even in the semi-arid sections near Qatna, was ideal grazing ground. So much so, that when Mari's territory was once experiencing a particularly severe dry season, its sheep were sent south of Yamhadian domain (V: Is; II: 66). Later, an Alalah tablet of level VII, AT * 349, noted the delivery of 28,800 sheep, tribute of Carchemish to its overlord in Yamhad.

But it was in the trade of horses, early in the second millennium, that Northern Syria seems to have played a major role. The early history of the horse as preserved in epigraphic elements can, for our purposes, be recounted in a brief amount of space. Once mentioned in the time of Sulgi, the horse is also known from Cappadocian texts where it is written syllabically si-sé-e.4) When the Mari Age unfolded, the

shipped on the Euphrates were exports of North Syria. From the Amanus, Sargon, his successors, and Gudea quarried alabaster. In addition, the region between Aleppo and Carchemish acquired a reputation for its marble and gypsum. From further south, red and yellow ochre were mined. When pulverized and mixed in liquids, the result served to brighten many a temple's wall.

I) Dossin, "Une lettre de Zimri-Lim, roi de Mari, a Iarim-Lim, roi d'Alep," Proc. of the 23 rd Int. Cong. of Or., (Cambridge, 1956), 121-123.

2) Compare Arabic samidld, 'semolina' still employed extensively today in the Middle East for the confection of pastries. Burke, $A R M T$ XI, p. 129, translates 'fleur de farine'; Birot, $A R M T$ IX, p. 262, ( $(23)$, renders 'farine de graut (?).'

3) Bottero, $A R M T$ VII, pp. 246-25 I ( $\ \ 59-64)$; Birot, $A R M T$ IX, pp. 296-302 $\left(\int 8 \mathrm{I}-9 \mathrm{I}\right)$.

4) Always in the formula GAL si-sé-e. For early materials concerning the horse, see A. Salonen, Hippologica Accadica (Helsinki, 1955), p. I 3 ff., and A. Kammenhuber, Hippologica Hetbetica (Wiesbaden, 196r), p. I 3 ff. In his review of Kammenhuber's book, Goetze posits two phases in which the introduction of the horse into the 
horse does not seem to have been of any importance in warfare. But royalties discovered in its public display a worthy symbol of might and ostentation. Thus when Zimri-Lim is urged not to ride horses in his city for fear of offending the Akkadians, it is understood that such an action, at another time, would have pleased the semi-nomadic Haneens (VI: 76: 19-25). Earlier, Šamsi-Adad requested YasmahAdad's famed chariot team, for he had planned to impress Ešnunna's delegation which was to be present at his akitu-ceremonies (I: 50). Designed for use in such important functions, horses naturally fetched a high price. When Išhi-Adad of Qatna offered two horses to IšmeDagan, valued by him at 600 shekels of silver, he was sorely disappointed by the token gifts he received in exchange. ${ }^{1}$ )

The horse does not seem to have been bred in North Syria, however, Qatna, Carchemish, and Chagar Bazar, imported the animal from Anatolia, before making it available to more southerly regions. Zimri-Lim received the following from his ambassador in Carchemish: "I have spoken [to Aplahanda] concerning the white horses. He (answered) thus: "There are no white horses for chariots (here). I shall write to where there are and they will send (them) to me. Until then, I will dispatch brownish horses from Harsama [in Anatolia]." 2)

Fertile Crescent was affected: the first in the third millennium by the Hurrians, the second just before the middle of the second millennium by the Indo-Europeans, JCS 16 (1962), pp. 34-35. But see now Civil, JCS 20 (1966), 1 $21-2$.

I) See above. According to the code of Hammurapi, the price of an ox was no more than 20 shekels of silver $(\oint 24 \mathrm{I})$. The Mari archives confirm this value, Birot, $A R M T$, p. $299\left(\$ 85,2^{\circ}\right)$. In Old Assyrian times, the price of donkeys averaged twenty shekels, some selling for as low as twelve, others as high (exceptional) as thirty. The price probably depended on the donkey's breed and age. (Cf. Garelli, Les Assyriens en Cappadoce, 299). One example from Old Babylonian times shows one donkey sold at the miserly rate of five and a half shekels of silver, CAD. I: I I I. Thus a horse was worth fifteen oxen, and an equal, if not more, number of donkeys.

2) Dossin, $R A$, 35 (1938), p. I2. On this text, see Weidner, "Weisse Pferde im Alten Orient," $B O, 9$ (I952), p. I 57 ff. For location of Haršama (Hittite Huršam(m)a), consult further, Balkan, Letter of Anum-Hirbi, p. 57; Kammenhuber, Hippologica Hetbetica, p. 36, n. 143 . It is possible that the lively export of 'black donkeys' from the Damascene region to Anatolia survived the collapse of the Kültepe kärum. (Cf. J. Lewy, "Ammuritica," HUCA, 32 (1961), 71-74; Garelli, Les Assyriens en Cappadoce, 299 ff.). 
A century later, the archives of Alalah VII record royal interest in horses $\left(\mathrm{AT} *_{240}\right.$; $*_{245}$ ). AT $*_{26} 6$ lists various recipients of grain; among them the stables of the 'Great King,' probably that of Yamhad, are mentioned (I. 48; 70). ${ }^{1}$ )

Yambad, Carchemish, and other North Syrian states also traded finished products which were either manufactured in local shops or, to a larger degree, imported from other centers. Often, it is not possible to determine into which category fell some of the garments shipped by Carchemish and Yamhad: mardatu, bassilatu, kaballu, and birum. ${ }^{2}$ ) However, the TÚG-yambadu, often included in gifts from both YarimLim and Aplahanda, must have been fabricated and/or designed according to the latest North Syrian style. ${ }^{3}$ ) While it is possible that the garments brought to Mari from Byblian salons had passed through North Syrian intermediaries, ${ }^{4}$ ) those that were created in Kaptaru, 'Crete,' surely took that route.

Mari has the distinction of being, so far, the first city whose archives contain unequivocal reference to trade with the Aegean island. From there, Zimri-Lim imported cloth, some gold vessels, a wooden (?) instrument, and a golden weapon whose pommel was incrusted with lapis-lazuli.5) As this stone could have been mined chiefly from Afghanitani sources, and gold obtained mainly from Egyptian regions, this last object offers a capsule comment on the Cretan economy in the Middle Bronze Age.

I) Salonen, Hippologica, p. I4, n. I; Kupper, Nomades, p. 36; J. Lewy, “Ammuritica," HUCA, 32 (I96I), 72.

2) Mardatu: $A R M$ VII: $238: 4,12 ; R A, 36$ (1939), p. 48: 2, 7. For other references, see Bottero $A R M T$, VII, p. $220\left(\left(78,15^{\circ}\right)\right.$. Compare also Ugaritic mrdt UT: 19: I 546.

Bassilatu: $A R M$ VII : 235: 5, 13; $R A, 36$ (1939), p. 48: 3, 8. For other references, consult $A H w$, p. I Io "etwa Kopftuch"; Bottero, $A R M T$, VII, p. $276\left(\$ 78,2^{\circ}\right)$. Kaballu: $A R M$ VII: 238: 6. For other references, see $A H w$, p. 4I4; Bottero, $A R M T$, p. $279\left(\$ 78,9^{\circ}\right)$.

Hirum: $A R M$ V: I $3: 8,(\mathrm{XV}$, p. 258). Further, $A H w$, p. 348; CAD, H, p. 201; Bottero, $A R M T$, VII, p. $278\left(\S 68,7^{\circ}\right)$.

3) $A R M$ VII: $238: 3$, I I IX: I02: 7. Also Bottero, $A R M T$ VII, p. $27^{8}\left(\left(7_{78}, 8^{\circ}\right)\right.$.

4) Dossin, Syria, 20 (1939), III.

5) Ibid., pp. I I I-I I 2. 
Except for extensive wooded areas ${ }^{1}$ ), the island was blessed with little natural resources with which to boast. Before 2000 B.C., its civilization was no more advanced than that of any other Aegean area. As the millennium turned, a vital and powerful culture grew almost overnight. It included palaces which strongly resembled Egyptian and, to a lesser degree, Mesopotamian parallels (Mari, Alalah VII). ${ }^{2}$ ) During the Middle Minoan I period (ca. 1950-1850), trade between Crete and the Near East is indicated by the presence of Minoan object found in Egypt, Cyprus, Byblos, Ugarit, and Qatna. On the other hand, Asiatic artifacts have been uncovered on Minoan soil, accentuating the testimonies for interconnections in the ancient world ${ }^{3}$ ). As a result of these foreign activities, Crete entered a world in which the written word was mandatory for those who wished to record economic transactions. Spurred, the Minoans either adopted or evolved after Near Eastern patterns, a system of syllabic notation which present-day scholars call 'hieroglyghic Minoan'. It is this system which, in time, graduated into Linear A; the last was responsible for ushering in a historical age for the Aegean. 4

Crete of the Early Palace Period seems to have witnessed a great increase in its population and in the number of inhabited areas:

Not only do the sites come closer together, but new places are built, around which, as at Mallia, groups of ordinary houses cluster, forming towns. Nothing of this sort had existed in the Early Minoan age. Far reaching social and political changes must have taken place, but we can surmise what these were only in terms of analogy; thus a more powerful dynasty may have taken the lead, a monarchical

I) A first millennium B.C. lexical text (von Soden: $J B$ ) speaks of Kaptaru as the source of Kullaru and sarbätu types of trees; apparently these were varieties of poplars. Cf. $A H w$, p. 445, s.v. Kaptaru, and CAD S, p. I08, s.v. sarbatu.

2) A. W. Lawrence, "The Ancestors of the Minoan Palaces," $B S A$, Annual, 46 (195 I), pp. 8 I-85. However, Graham does not agree; see his succinct presentation of the problems in his, "The Relations of the Minoan Palaces to the Near Eastern Palaces of the Second Millennium," Mycenaean Studies, Wingspread, I96I (Madison, 1964), pp. I95-214.

3) Hutchinson, Prehistoric Crete (Penguin, 1962), pp. 105-106.

4) Wider studies of the Cretan Middle Bronze Age should be consulted, among which, see F. Schachermayr, Die Minoiscbe Kulture des Alten Kreta (Stuttgart, 1964), chap. VI, VII, with appropriate bibliography. 
centralization replaced feudal dispersal and city-states developed from villages or small market-towns. 1)

Recently, C. H. Gordon has advanced a theory which, if ever proven correct, would go far to explain the development of Minoan script, the increase in population, and the changes in social institutions. Noticing the presence of Egyptian, Semitic, and Hurrian personal names in Linear A lists of ca. 1600, he reconstructed an era in which large numbers of Asiatics began to colonize Crete. Originating from the Nile Delta, the new settlers had been forcibly ejected by the powerful leaders of the Twelfth Dynasty (ca. 1990). ${ }^{2}$ ) It is possible that such an event may have begun earlier, guided by the successful Eleventh Dynasty pharaoh, Mentuhotpe II (ca. 2060). A similarly enigmatic burst of achievement, occurring in Greece of the Shaft-Grave period, has been related to the area's occupation by the Hyksos, another group of dispossessed Delta Asiatics. ${ }^{3}$ )

Other finished products were also sent to Egyptian and Mesopotamian markets from North Syrian centers. To Egypt went a number of Aegean influenced vessels, some of which were made of precious metals.4) To Mesopotamia were delivered a variety of utensils, some imported from Crete, ${ }^{5}$ ) others manufactured in Northern Syria. ${ }^{6}$ ) A small selection of gold and silver goblets and containers were listed as shipment from Aplahanda and Yarim-Lim. ${ }^{7}$ ) North Syria seems also to have manufactured and propagated a style of seal cylinders, which were exported south to Sippar. ${ }^{8}$ )

I) P. Demargne, Birth of Greek Art (New York, I964), p. 84 .

2) Concisely stated in his "The Greeks and the Hebrews," Scientific American, 2 I 2 (165), pp. 102-I I I. See also the "Forward to the Second Edition," in The Common Background of Greek and Hebrew Civilizations (New York, 1965), pp. 5-8, 302. Without any elaboration a similar idea can be found in Wace and Stubbings, $A$ Companion to Homer (London, 1962), p. 336.

3) Stubbings, "The Rise of Mycenean Civilization," $C A H^{2}, \mathrm{II}, \mathrm{I}_{4}$ (I963), chapt. III-IV (pp. 9-I4); Astour, Hellenosemitica, pp. 92 ff., with documentation.

4) Included in the treasure from Tôd, above.

5) Dossin, Syria, 20 (1939), p. I I ; above, p. 75.

6) GAL yamaditum: $A R M$ IX: 268: 1; $271: 6$.

7) $A R M$ VII: 238; See further, Bottero, $A R M T$ VII, pp. 308-316. $\left(\$ 93,3^{\circ}\right.$, $7^{\circ}, 9^{\circ} ;(94,10)^{\circ}$.

8) Porada, Cbronologies in Old World Archaeology, p. 172. 
Although slaves were probably included in the large repertoire of Northernmost Syria's traded objects, little direct evidence exists at present. ${ }^{1}$ ) One can note, however, the number of slaves from Middle Kingdom Egypt who bore names of the type that is well attested in Middle Bronze Syria. ${ }^{2}$ )

While this institution was well-known, even regulated by law-codes, another one, less unhappy, was also prevalent. Unlike Ugarit, whose archives yielded long lists of workers belonging to the same 'guild,' those of Mari scatter the individual members through the documents. We do perceive the existence of a class of artisans who ambulated from one land to another, one of whom the Greeks of later times named dèmioergoi (Odyssey 17: $38 \mathrm{I}-386) .^{3}$ ) As an example from Mari, there is the letter of Yasmah-Adad who pleads with his father to send Meranum, a doctor, to effect the cure of one, Rišiya ( $A R M$ I: II s). Having a reputation to preserve, such physicians would often travel long distances to study a certain drug (IV: $\left.65^{4}\right)$.) Another missive contains the complaints of Zimri-Lim's functionary who asks for a doctor and a mason (II: 127). Another official, Yaqqim-Adad, explains the manner in which an artisan was given employment: "I requested from my lord [Zimri-Lim] a house builder, and they have given me Ahum, the mason. I have had him build the ice-house. He finished the ice-house, then this man went to Mari (II: IOI ; 20-24; cf. V: 28)." In another letter, Yasmah-Adad writes to his father: "Write to Tuttul so that they send to you a farmer capable of handling a plow and (of tracing) a furrow. Then send him to 'IM.LÚ-ti [Tarhunda-ziti (?)] (I; 63:5-12)."

Because his function was specialized and of immense benefit to society, an artisan, whether a house-builder, a smith, a physician, or

I) Slaves from Ursum and Haḩum are cited by Leemans, Foreign Trade, pp. IIO-III.

2) Helck, Beziebungen, pp. 79-89, with bibliography.

3) The Mari and other Old Babylonian texts indicate the organization of artisans under an aklu, a sitimgallu, 'overseer.' Such workers were usually connected with the palace to whom they owed their holdings and livelihood, possibly during the duration of their stay. For an example, consult CAD I, pp. 296-297, s.v. itinnu A.

4) See the in-depth study, „Les médecins au royaume de Mari," by A. Finet in the Annuaire de l'Institut de Pbilologie et d'Histoire Orientales et Slaves, I4 (I954-56), I 23-I44. 
a cook, was not allowed to remain long unemployed: "To YasmahAdad, thus (speaks) your father, Šamsi-Adad: "Ili-[Dagan], the mason [c.f. V: 28: 5,7 ]; why is he there? Why is he idle? There the house is not built; the palace is not built. Send him to Subat-Enlil. He will not be transferred here permanently (II: 2: 1-14)."

However, one cannot be certain whether these ambulating workers enjoyed undividedly the fruits of their labor. It is possible that those with whom they were associated received benefits from the court which retained their services. From North Syria, we know of a Yamhadian who was engaged by Mari as a skilled woodcarver ( $A R M$ XIII : 42). He was perhaps to be employed in installing a panel of cedar that had been imported from Carchemish (XIII: 7). There, he was provided with ration and lodging, apparently separate, with other artisans of foreign derivation. $A R M$ XII: 747 groups together skilled workers, from, among other regions, Hașor, Yamhad, Carchemish, and Emār, who were supplied with choice cuts of meats. ${ }^{1}$ )

Since Mesopotamia was also an important center for specialized craftsmanship, $\left.{ }^{2}\right)$ traffic often went from south to north. Šamsi-Adad to his son at Mari (ARM I: 83: 7-13): "As to the näru-singer [whom Aplahanda had requested of you], give him (one) of your (own) eštalüsingers. All your eštalü-singers are (equally) excellent, (but) one of these estalu-singers is no less dispensable (than the other). As to the female näru-singer whom he has requested of you, look around, and give him one who is dispensable."

On a wider scale, such a diffusion of demmioergoi must have been quite prevalent throughout the Mediterranean world, offering the culture of one civilization to the eyes of another, and aiding in the creation, late in the Bronze Age, of an atmosphere in which traditions could be shared in common.

I) But see the interpretation of the same text by Birot, $A R M T$ XII, pp. 4-5.

2) The Mari archives conserve a plethora of skilled positions. See Bottero, $A R M T \mathrm{XV}$, pp. 318-319, s.v. MÉTIERS. A more detailed study on the circulating artisans was read at the $A O S$ meetings in New Haven, Conn., March 22. 1967. It is hoped to be published soon. 